\title{
NMR and quantum chemical studies on association of 2,6-bis(acylamino)pyridines with selected imides and $2,2^{\prime}$-dipyridylamine
}

\author{
Borys Ośmiałowski • Erkki Kolehmainen • \\ Ryszard Gawinecki • Reijo Kauppinen • \\ Juha Koivukorpi · Arto Valkonen
}

Received: 8 June 2010/Accepted: 8 July 2010/Published online: 20 July 2010

(C) The Author(s) 2010. This article is published with open access at Springerlink.com

\begin{abstract}
Association constants of 2,6-bis(alkylcarbonylamino)pyridines (alkyl = methyl or ethyl) and their perfluoroalkyl analogues with succin- and maleimide as well as with 2,2'-dipyridylamine (complementary DAD and ADA hydrogen bonding motifs are responsible for formation of the associates) have been determined by NMR titrations and quantum chemical calculations. Interactions of 2,6-bis (alkylcarbonylamino)pyridines with imides differ by character from these of perfluoroalkyl analogues. Such large difference was not observed for the 2,2'-dipyridylamine associates. Since fluorine atoms cause carbonylamino groups to be stronger hydrogen bond donors, perfluorinated species of this type were found to be more stable. Single crystal X-ray structures of 2,6-bis(trifluoromethylcarbonylamino)pyridine and 2,6-bis(pentafluoroethylcarbonylamino)pyridine have been also determined.
\end{abstract}

Keywords Association - Hydrogen bond .

Selective binding $\cdot$ NMR $\cdot$ DFT calculations

Electronic supplementary material The online version of this article (doi:10.1007/s11224-010-9646-2) contains supplementary material, which is available to authorized users.

B. Ośmiałowski $(\bowtie) \cdot$ R. Gawinecki

Faculty of Chemical Technology and Engineering,

University of Technology and Life Sciences, Seminaryjna 3,

85-326 Bydgoszcz, Poland

e-mail: borys.osmialowski@utp.edu.pl

E. Kolehmainen · R. Kauppinen · J. Koivukorpi · A. Valkonen Department of Chemistry, University of Jyväskylä,

P.O. Box 35, 40014 Jyväskylä, Finland

\section{Introduction}

Intermolecular multiple hydrogen bonding (HB'ing) is of major importance in biochemistry and supramolecular chemistry. It plays a crucial role in formation of the double helix of DNA [1] and in action of artificial receptors used in biochemistry $[2,3]$. Hydrogen bonding is the most common non-covalent interaction [2,4] observed in biosensing, self-complementary aggregation, and non-covalent polymer formation [5-7]. Significance of hydrogen bonding is based on its directionality and reversibility [6]. There are few factors that influence the HB'ed complex stability. These are number of hydrogen bonds, hydrogen bonding pattern $[8,9]$, secondary interactions $[10,11]$. Also the tautomeric equilibrium may be responsible for forming variously stabilized associates. This is due to group and HB'ing pattern changes upon proton transfer.

It is known that secondary interactions result in strengthening of the AAAA/DDDD-type [12] association in comparison with that of ADAD/DADA [13]. The same is true for AAA/DDD [14-17] versus DDA/AAD [18, 19] versus ADA/DAD pairs [7, 8, 20-22]. Although the ADA and the DAD motifs are not self-complementary, their selfassociation is still possible due to rotamerism (Scheme 1) or tautomerism [23-26]. On the other hand, 2,6-bis(acrylamido) pyridine does not form dimers [27].

Steric hindrance [28-31] weakens basicity of 2,6-ditert-butylpyridine [32]. Thus, the parallel effect should be observed for non-covalent interactions. Also the electronic repulsion is believed to be responsible for weakening of the association of bis(acetylamino)triazine derivatives with imides [33].

The organized structures of 2,6-diacetylaminopyridines with imides were obtained by their aggregation on the $\mathrm{Ag}$ surface [34]. Hydrogen bonding in these compounds was 
Scheme 1 Self-assembly of the DAD motif due to the group rotation resulting in the DADA pattern<smiles>[R]C(=O)Nc1cccc(NC(=O)PC)n1</smiles>

D A D

studied mainly from the point of view of binding in nucleic bases [35-37], bisurea derivatives [38], structures stabilized by $\pi-\pi$ interactions [39], receptors for barbituric acid [40], and fluorine anion [41], enhancement of the fluorescence of conjugated polymeric chain upon complexation [42], cooperative catalyst [43], and potentially drug delivery nanomaterials [44]. Hydrogen bonding and possibility of the complex formation in solution and in solid state between the 2,6-diacetylaminopyridine and enolate derivative of barbituric acid has been shown recently by the X-ray diffraction [45]. Interestingly, conformation of the amide group in $\mathrm{N}$-(pyrimidin-2-yl)pentafluorobenzamide derivatives was found to be of the cis type, especially when the 2,6-diacetylaminopyridine derivative stabilized this form by hydrogen bonding [46].

Feibush have suggests that 2,6-bis(pivaloylamino)pyridine does not form complexes with imides due to steric crowding [47]. On the other hand, stronger hydrogen bonding capability of proton in the $\mathrm{NHCOCF}_{3}$ group (as compared to that in $\mathrm{NHCOCH}_{3}$ ) is expected to strengthen the complex stability. 2,6-Bis(trifluoromethylcarbonylamino)pyridine has been investigated as a hydrogen bonding counterpart stabilizing the flavin radical anion [48] and as a hydrogen bonding receptor for barbiturate [49]. The acylation of amino moiety, however, not always led to the greater stability of non-covalent associates [33]. It was suggested that this is due to electronic repulsion/secondary repulsive interactions.

Imides are complementary by hydrogen bonding to with 2,6-bis(alkylcarbonylamino)pyridines. The triple hydrogen bonds are expected to strengthen the association especially with the perfluoroalkyl derivatives. Clarification of these interactions between succin- and maleimide, 2,2'-dipyridynamine and 2,6-bis(alkylcarbonylamino)pyridines is the main goal of this article.

\section{Results and discussion}

Formulas of 2,6-bis(acylamino)pyridines 1-4 with 2,2'dipyridylamine (5) and imides (6) and (7) as well as numbering of positions in their molecules are depicted in Fig. 1.

\section{NMR}

Since NMR chemical shifts of the NH/OH protons are sensitive to the concentration and solvent properties, the ${ }^{1} \mathrm{H}$ NMR<smiles></smiles>

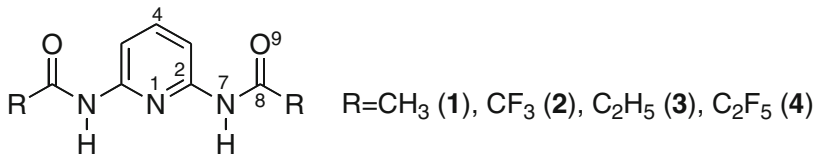<smiles>c1ccc([NH2+]c2ccccn2)nc1</smiles>

5

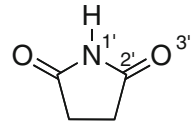

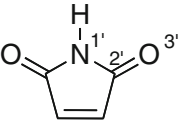

Fig. 1 Formulas of the compounds studied and atom numbering

spectra of all neat compounds and their 1:1 mixtures were recorded at the same concentration (see "Experimental"). On the other hand, their ${ }^{13} \mathrm{C}$ and ${ }^{15} \mathrm{~N}$ spectra were run for the saturated solutions. The chemical shifts are available in the Supporting Information Section (SI, Table S1). H7 protons in $\mathbf{2}$ and $\mathbf{4}$ were found to be more acidic than these in $\mathbf{1}$ and $\mathbf{3}$. Perfluorination of the alkyl groups results in deshielding of the ${ }^{1} \mathrm{H} 7$ signal by $0.7-0.8 \mathrm{ppm}$.

The complexation induced shift (CIS) values of the amide protons $(\delta(\mathrm{H} 7))$ for $\mathbf{1 - 4}$ and their 1:1 mixtures with 2,2'-dipyridylamine (5), succinimide (6), and maleimide (7) are collected in Table 1 (see also Table S1).

Table 1 Complexation induced shifts (CIS) $\left[\Delta \delta(\mathrm{H} 7) / \Delta \delta\left(\mathrm{H} 1^{\prime}\right)\right]$ for the 1:1 mixtures of 2,6-diacetylaminopyridines (1-4) with 2,2'dipyridylamine (5), succinimide (6), and maleimide (7) and association constants $\left(K_{\text {assoc }}\right)$

\begin{tabular}{lllr}
\hline Entry & Mixture & CIS & $K_{\text {assoc }}$ \\
\hline 1 & $\mathbf{1}+\mathbf{5}$ & $1.74 / 1.35$ & 420 \\
2 & $\mathbf{2}+\mathbf{5}$ & $1.86 / 1.90$ & 540 \\
3 & $\mathbf{3}+\mathbf{5}$ & $1.20 / 1.01$ & 240 \\
4 & $\mathbf{4}+\mathbf{5}$ & $1.09 / 1.08$ & 270 \\
5 & $\mathbf{1}+\mathbf{6}$ & $0.97 / 3.03$ & 700 \\
6 & $\mathbf{2}+\mathbf{6}$ & $0.06 / 0.20$ & 40 \\
7 & $\mathbf{3}+\mathbf{6}$ & $0.90 / 2.41$ & 620 \\
8 & $\mathbf{4}+\mathbf{6}$ & $0.03 /^{\mathrm{a}}$ & $<20$ \\
9 & $\mathbf{1}+\mathbf{7}$ & $0.36 / 1.73$ & 280 \\
10 & $\mathbf{2}+\mathbf{7}$ & $0.05 /^{\mathrm{a}}$ & 30 \\
11 & $\mathbf{3}+\mathbf{7}$ & $0.31 / 1.08$ & 230 \\
12 & $\mathbf{4}+\mathbf{7}$ & $0.02 /^{\mathrm{a}}$ & $<20$ \\
\hline
\end{tabular}

a Signal not observed 
The association constants (Table 1) show that the most stable complexes are $\mathbf{1}+\mathbf{6}$ and $\mathbf{3}+\mathbf{6}$. It is noteworthy that $K_{\text {assoc }}$ obtained now are comparable to these for other triple hydrogen-bonded systems [44, 50-52].

Based on the CIS and $K_{\text {assoc }}$ values for mixtures of 1-4 with 5 (Table 1 ) and $\delta(\mathrm{H} 7)$ for the neat $\mathbf{1 - 4}$ (Table S1) one can see that perfluoroalkyl groups increase the hydrogen bond donor properties of H7. This results in increasing stabilities of complexes carrying the electron acceptor groups. Contrary to $\mathbf{1}$ and $\mathbf{3}$, negligible effect of complexation of succin- and maleimide was found for perfluoro analogues $\mathbf{2}$ and $\mathbf{4}$ implying that their association with those imides is very weak. Such weak complexation was earlier observed in mixture of 2 with flavin [48]. An explanation for the weak association of $\mathbf{2}$ and $\mathbf{4}$ with $\mathbf{6}$ and 7 can be that $\mathrm{CF}_{3}$ and $\mathrm{C}_{2} \mathrm{~F}_{5}$ groups create electronic repulsions towards the hydrogen bond acceptors, i.e., carbonyl oxygens of the imide. Differing from that in $2,2^{\prime}$ dipyridilamine partial rotation of the pyridine ring around the N1-C2 bond [53] (Fig. 2) causes that this molecule can adopt a geometry that allows complex formation even when substituents show some repulsion with the pyridine rings of 5 .
Owing to low rotation barrier of the perfluoroalkyl groups around the $\mathrm{C}-\mathrm{N}$ bond in the amide [46], both the trans and cis forms (Scheme 2) may be expected to be present in the complexes of $\mathbf{2}$ and $\mathbf{4}$ with imides $\mathbf{6}$ and $\mathbf{7}$. One should keep in mind, however, that electronic repulsion between the carbonyl oxygen of $\mathbf{6}$ and 7 and fluorine or oxygen atoms of $\mathbf{2}$ and $\mathbf{4}$ may destabilize the said complexes (Scheme 3).

Additional ${ }^{1} \mathrm{H}$ NMR experiments were also run with three component mixtures to clarify what happens in case of competitive binding. The detailed results and discussion can be found in SI.

\section{X-ray structural data}

Single crystal structures of 2 and 4 (Fig. 3) show that all the substituent $\mathrm{C}$ atoms (except these of $\mathrm{CF}_{3}$ groups in 4) lie almost in the plane of pyridine ring. Although twodimensional schematic drawings of $\mathbf{2}$ and $\mathbf{4}$ indicate these compounds to be symmetrical, there is no crystallographic mirror plane or other symmetry element found along the N1 $\cdots \mathrm{C} 4-\mathrm{H} 4$ axis. Despite the amide side chains in 2,6bis(acylamino)pyridines are slightly twisted with respect to

Fig. 2 The optimized (M05/6$31 \mathrm{G}(2 \mathrm{~d}, \mathrm{p})$ level) structure of $\mathbf{1}+\mathbf{5}$ and $\mathbf{1}+\mathbf{6}$ complexes

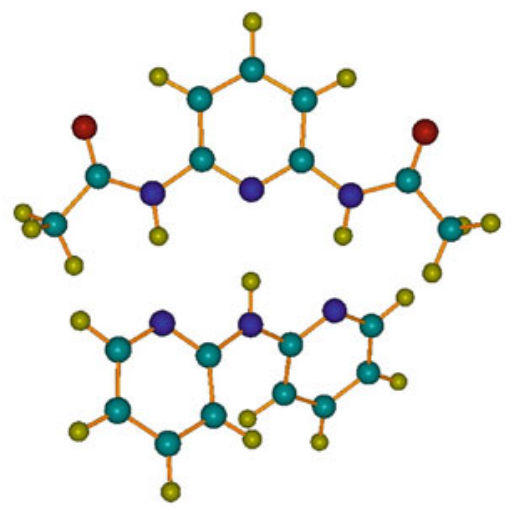

$\mathbf{1}+\mathbf{5}$ (top view)

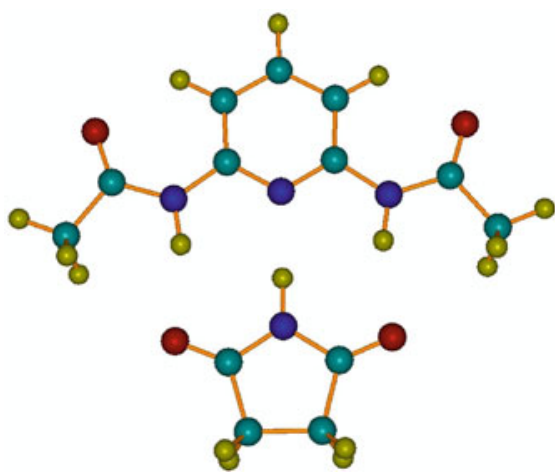

$1+6$ (top view)

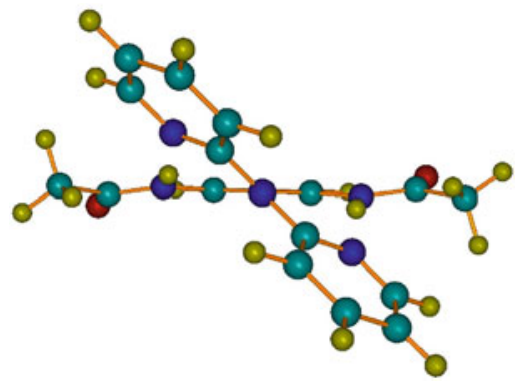

$\mathbf{1}+\mathbf{5}$ (view along N1'/N1 axis)

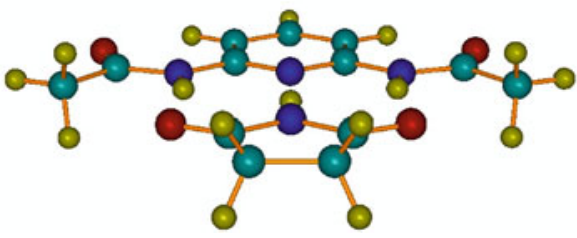

$\mathbf{1}+\mathbf{6}$ (view along $\mathrm{N} 1$ '/N1 axis) 
<smiles>CCC(=O)NC(C)C</smiles>

trans<smiles>CNC(=O)NC(C)C</smiles>

cis
Scheme 2 The trans and cis forms of the carbonylamino group

the pyridine ring (Table S12) their geometries are comparable. Figure 2 shows molecular structures of $\mathbf{2}$ and $\mathbf{4}$ as the ORTEP-diagrams [54]. Compounds $\mathbf{2}$ and $\mathbf{4}$ are held in the crystal phase by a net of the intermolecular hydrogen bonds (Fig. S1, for distances $\mathrm{N} 7 \cdots \mathrm{O} 9$ and $\mathrm{N}\left(\mathrm{R}_{2}\right) \cdots \mathrm{O}\left(\mathrm{R}_{2}\right)$ see Table S12).

\section{Calculations}

Molecular geometries were calculated using the DFT method (M05). It is less time-invasive than, for example, calculations at the MP2 level. The M05 functional is optimized for calculation of many types of non-covalent interactions. This methodology has been previously compared [55] by us with B3LYP and MP2 ones for noncovalent intermolecular interactions in 1,8-naphthyridine derivatives. Detailed geometry data for complexes are collected in SI (Tables S3-S9).

Geometries of the optimized complexes support the results obtained by ${ }^{1} \mathrm{H}$ NMR spectrometry. Substitution of $\mathrm{H}$ by $\mathrm{F}$ atoms in the acylamino moieties makes $\mathrm{H} 7$ protons more acidic. The $\mathrm{H} 7 \cdots \mathrm{X} 3^{\prime}$ distance $\left(\mathrm{X}^{\prime}{ }^{\prime}\right.$ is the nitrogen and oxygen atom in 5 and $\mathbf{6}$ (and 7), respectively) shows that hydrogen bond is always shorter in the fluorinated derivatives. However, there are some exceptions: $\mathrm{H} 7 \cdots \mathrm{X} 3^{\prime}$ distances in $\mathbf{4}+\mathbf{6}$ and in $\mathbf{3}+\mathbf{6}$ are practically identical. Moreover, $\mathrm{H} 7$ in $\mathbf{4}+\mathbf{7}$ is more faraway from $\mathrm{X}^{\prime}$ than in $3+7$. As a result of shortening of the $\mathrm{H} 7 \cdots \mathrm{X} 3^{\prime}$ distance, the $\mathrm{H} 1^{\prime} \cdots \mathrm{N} 1$ hydrogen bonds in $\mathbf{2}+\mathbf{5}$ and $\mathbf{4}+\mathbf{5}$ complexes are noticeably shorter than these in $\mathbf{1}+\mathbf{5}$ and $\mathbf{3}+\mathbf{5}$. The $\mathrm{X} 3^{\prime} \cdots \mathrm{C} 8$ and $\mathrm{X} 3^{\prime} \cdots \mathrm{C}\left(\mathrm{R}_{3}\right)$ distances are noticeably larger in the complexes carrying the $\mathrm{CF}_{3}$ and $\mathrm{C}_{2} \mathrm{~F}_{5}$ groups. Lower values of $\mathrm{C} 2-\mathrm{N} 7-\mathrm{C} 8$ angle (Table S7) in fluoroalkyl as compared to these in alkyl derivatives suggest that repulsion between the pyridine ring of $\mathbf{5}$ or oxygen atoms of imides and fluorine atoms of $\mathbf{2}$ and $\mathbf{4}$ takes place. It is noteworthy that energy of the complex formation for

Scheme 3 Electronic interactions in the $\mathbf{2}+\mathbf{6}$ complex: arrows were used to show repulsions

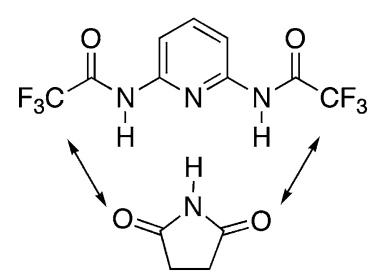

trans/trans form

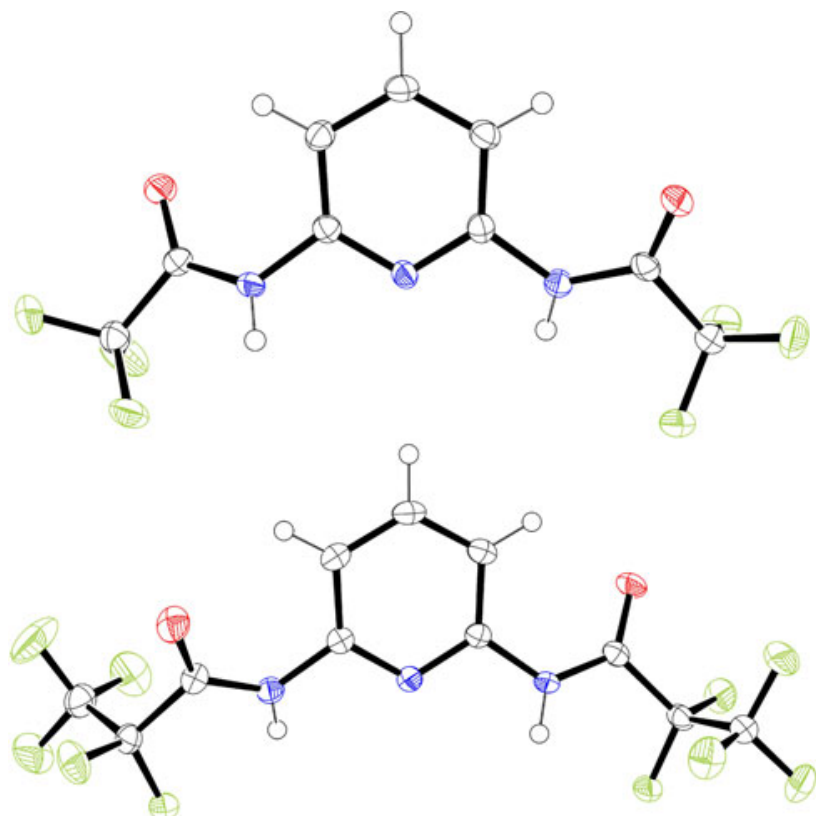

Fig. 3 The ORTEP-diagrams [54] of the compounds 2 (upper) and 4 with thermal ellipsoids drawn at $50 \%$ probability level (heteroatoms displayed as octant shaded model)

fluorinated derivatives $\mathbf{2}$ and $\mathbf{4}$ with imides $\mathbf{6}$ and $\mathbf{7}$ is ca. $18.4 \pm 1 \mathrm{~kJ} / \mathrm{mol}$ lower than that of $\mathbf{1}$ and $\mathbf{3}$ with the same imides (Table S10).

The intermolecular interactions influence electron distribution in each complex. The orbital contours of $\mathbf{1}+\mathbf{6}$ and $\mathbf{2}+\mathbf{6}$ show the interaction of the hydrogen bond character (exemplified on Fig. 4). Other orbitals (HOMO20 and HOMO-14, HOMO-27 (no H-bond is visible at this contour level), and HOMO-24, HOMO-29 and HOMO-30, HOMO-35 and HOMO-41, HOMO-36 and HOMO-42) involved in hydrogen bonding in $\mathbf{1}+\mathbf{6}$ and $\mathbf{2}+\mathbf{6}$ were also considered. There are two orbitals in $\mathbf{2}+\mathbf{6}$ (HOMO38 and HOMO-40) that show the electron repulsion is present. No such orbitals were found for the $\mathbf{1}+\mathbf{6}$ complex. Orbital contours are collected in the SI.

\section{Conclusions}

Complexes of 2,6-bis(alkylcarbonylamino)pyridines with succin- and maleimide as well as with $2,2^{\prime}$-dipyridylamine are stabilized by the triple hydrogen bonds. Substitution of

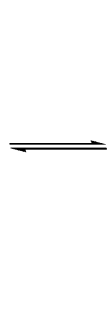

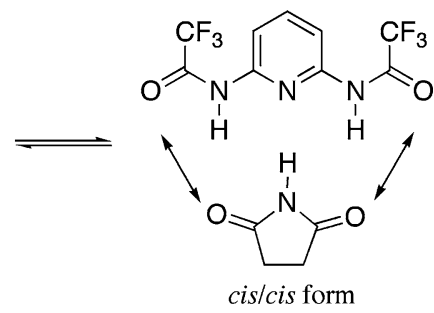


<smiles>CC(=O)Nc1cccc(NC(C)=O)n1</smiles><smiles>O=C(Nc1cccc(NC(=O)C(F)(F)F)n1)C(F)(F)F</smiles><smiles>CC(=O)NC(C)=O</smiles>

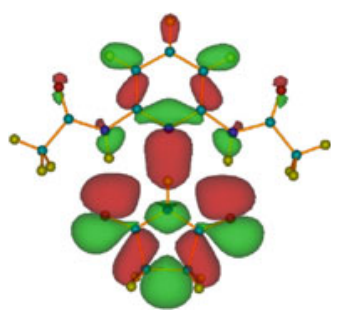

Fig. 4 Molecular orbitals (HOMO-9) of $\mathbf{1}+\mathbf{6}$ and $\mathbf{2}+\mathbf{6}$ showing the intermolecular hydrogen bond (continuous electron density along hydrogen bong axis)

$\mathrm{H}$ by $\mathrm{F}$ in the alkyl parts of 2,6-bis(alkylcarbonylamino)pyridines makes the amide protons better hydrogen bond donor. On the other hand, strong intermolecular $\mathrm{CO} / \mathrm{F}$ electronic repulsion diminishes efficiency of these compounds to associate with imides whereas the conformational flexibility of $2,2^{\prime}$-dipyridilamine enables its association with 2,6-diacylaminopyridines. The association constants of imides and 2,2'-dipyridilamine with 2,6-diacylaminopyridines follow the concept of steric repulsion. The spectra of the double $(\mathbf{1}+\mathbf{4}$ and $\mathbf{1}+\mathbf{6})$ versus triple mixtures $(\mathbf{1}+\mathbf{4}+\mathbf{6})$ studied by ${ }^{1} \mathrm{H}$ NMR confirm complexes of imides with 2,6-bis(alkylcarbonylamino) pyridines to be much more stable than these with 2,6bis(perfluoroalkylcarbonylamino)pyridines, showing the selective binding of imides by non-fluorinated derivatives. The linear dependence between the association constants and the complexation induced shifts enables the latter to be used as a preliminary probe for relative complex stability. The agreement of the computational data (geometry, energy and visualization of molecular orbitals) with experimental one, including the electronic repulsion between oxygen and fluorine, suggests that DFT method is able to describe hydrogen bonding and electronic repulsion reliably.

\section{Experimental}

Synthesis

Compounds 1-4 were obtained by refluxing ( $2 \mathrm{~h}$ ) of the mixture of 2,6-diaminopyridine $(0.2 \mathrm{~g}, 1.8 \mathrm{mmol})$ and $2 \mathrm{~mL}$ of the appropriate acid anhydride. Excess of the latter compound was decomposed by addition of water $(10 \mathrm{~mL})$ and saturated aqueous sodium carbonate solution $(5 \mathrm{~mL})$. The obtained mixture was then extracted with chloroform
$(2 \times 15 \mathrm{~mL})$, organic layer dried $\left(\mathrm{Na}_{2} \mathrm{SO}_{4}\right)$, and evaporated to dryness under reduced pressure. The crude products were further purified by recrystallization. Melting points: 1, $199-202{ }^{\circ} \mathrm{C}\left(\mathrm{C}_{6} \mathrm{H}_{14} / \mathrm{AcOEt}\right.$, white powder $)$ (lit. $202-203{ }^{\circ} \mathrm{C}$ [56], $205-206{ }^{\circ} \mathrm{C}$ [57]), 2, $154-158{ }^{\circ} \mathrm{C}$ $\left(\mathrm{C}_{6} \mathrm{H}_{14} / \mathrm{AcOEt}\right.$, pale-yellow needles $), \quad 3,127-128^{\circ} \mathrm{C}$ $\left(\mathrm{C}_{6} \mathrm{H}_{14} / \mathrm{AcOEt}\right.$, white powder) and $4,105-107{ }^{\circ} \mathrm{C}\left(\mathrm{C}_{6} \mathrm{H}_{14} /\right.$ AcOEt, pale-brown crystals). Satisfactory elemental analytical data were obtained for synthesized compounds, i.e., 1 calcd C9H11N3O2 C 55.95, H 5.74, N 21.75, found: C 55.68, H 5.70, N 21.52, 2 calcd $\mathrm{C} 11 \mathrm{H} 15 \mathrm{~N} 3 \mathrm{O} 2 \mathrm{C} 59.71, \mathrm{H}$ 6.83, N 18.99 found: C 59.54, H 6.76, N 18.69, 3 calcd C9H5F6N3O2 C 35.90, H 1.67, N 13.95 found: C 35.73, H 1.64, N 13.78, 4 calcd C11H5F10N3O2 C 32.93, H 1.26, N 10.47 found: C $32.65, \mathrm{H} 1.22, \mathrm{~N} 10.27$. Compounds $\mathbf{5}-\mathbf{7}$ were commercially available and were used as obtained after drying in desiccator.

NMR

${ }^{1} \mathrm{H}$ NMR experiments were run with a Bruker Avance DRX 500 spectrometer equipped with an inverse detection 5-mm diameter probehead with a z-gradient for equimolar $\mathrm{CDCl}_{3}$ solutions at $303 \mathrm{~K} .{ }^{1} \mathrm{H}$ and ${ }^{13} \mathrm{C}$ NMR chemical shifts are referenced to an internal TMS ( $\delta=0.00 \mathrm{ppm})$. Owing to the limited solubility, ${ }^{13} \mathrm{C}$ and ${ }^{15} \mathrm{~N}$ spectra of all compounds are run for their saturated solutions. Acquisition and processing parameters are the same as reported earlier [58]. The 2D pulsed field z-gradient (PFG) selected ${ }^{1} \mathrm{H},{ }^{13} \mathrm{C}$ $\mathrm{HMQC}$, and ${ }^{1} \mathrm{H},{ }^{13} \mathrm{C} \mathrm{HMBC}$ experiments were run to assign reliably the ${ }^{13} \mathrm{C}$ NMR spectra [58]. ${ }^{15} \mathrm{~N}$ NMR chemical shifts (referenced to an external neat ${ }^{15} \mathrm{~N}$-natural abundance nitromethane, $\delta=0.0 \mathrm{ppm}$ ) are those obtained with the $\mathrm{PFG}{ }^{1} \mathrm{H},{ }^{15} \mathrm{~N}$ HMBC experiments [58].

\section{Association experiments}

Equimolar quantities $(0.089 \mathrm{mmol})$ of $\mathbf{1}(17.2 \mathrm{mg}), \mathbf{2}$ (26.9 mg), 3 (19.7 mg), 4 (35.7 mg), 5 (15.3 mg), 6 $(8.8 \mathrm{mg})$, and $7(8.6 \mathrm{mg})$ were dissolved in acetone $(10 \mathrm{~mL})$. Solutions of $\mathbf{1 - 4}(3 \mathrm{~mL})$ were then combined with solutions of 5-7 (3 mL) to obtain the $\mathbf{1}+\mathbf{5}, \mathbf{1}+\mathbf{6}$, $1+7,2+5,2+6,2+7,3+5,3+6$, and $3+7$ complexes. Additional $3 \mathrm{~mL}$ solutions of compounds 1-7 were kept to prepare the references. Evaporation of the solvent from all solutions prepared and drying of the residue in vacuum desiccator was followed by its dissolving in $\mathrm{CDCl}_{3}(0.6 \mathrm{~mL}) .{ }^{1} \mathrm{H}$ NMR spectra of chloroform solutions of the complexes were recorded within $1 \mathrm{~h}$. The CIS values were obtained by subtraction of the $\delta \mathrm{H} 7$ and/or $\delta \mathrm{H}^{\prime}$ values for the complexes from the chemical shift values of the neat compounds (reference). The NMR titrations were done for the constant concentration of 1-4. Equivalents of 
the solid titrants added equal to: $0.5-50$ for $\mathbf{5}, 1-10$ for $\mathbf{6}$, and 1-20 for 7 . The titration was continued to obtain the $\Delta \delta(\mathrm{H} 7)$ smaller than $0.1 \mathrm{ppm}$ upon addition of the next portion. The $\delta \mathrm{H} 7$ (probe) obtained are collected in SI (titration charts). The Benesi-Hildebrandt [59] equation was used to calculate the $K_{\text {assoc }}$.

\section{X-ray}

Single crystals of $\mathbf{2}$ and $\mathbf{4}$ used in the X-ray crystallographic experiment were obtained by slow evaporation of the solvent (chloroform) from NMR tube. The structural data for these compounds were collected at $123 \pm 2 \mathrm{~K}$ with a Bruker-Nonius KappaCCD diffractometer equipped with APEXII detector using the graphite monochromatized $\operatorname{MoK}_{\alpha}$ radiation $(\lambda=0.71073 \AA)$. Data were processed with DENZO-SMN [60]. The structures were solved by direct methods, using SIR-2004 [61], and refined on $F^{2}$, using SHELXL-97 [61]. The reflections were corrected for Lorenz polarization effects and absorption correction was not used. The $\mathrm{H}$ atoms bonded to $\mathrm{C}$ atoms were calculated to their idealized positions with isotropic temperature factors (1.2 times the $\mathrm{C}$ atom temperature factor) and refined as riding atoms. The $\mathrm{H}$ atoms bonded to $\mathrm{N}$ atoms were found from electron density map and fixed to distances of $0.88 \AA$ from $\mathrm{N}$ atom with isotropic temperature factor (1.2 times the $\mathrm{N}$ atom temperature factor). The figures were drawn with ORTEP-3 [54] and MERCURY [62]. Other experimental X-ray data are shown in Table 2. CCDC-763984 (2) and CCDC-763985 (4) contain the supplementary crystallographic data for this article. These data can be obtained free of charge at http://www.ccdc.cam.ac.uk/conts/retrieving. html [or from the Cambridge Crystallographic Data Centre (CCDC), 12, Union Road, Cambridge CB2 1EZ, UK; fax: +44 1223 336033].

\section{Calculations}

Calculations at the M05/6-31G(2d,p) level for geometry optimizations of all structures studied have been performed in Gaussian [63]. The energy minimum was confirmed by the frequency calculations (all positive frequencies were obtained). Energy of the complex formation was calculated as the difference between energy of the complex and a sum of the energies of its constituents. The basis set superposition error (BSSE) correction was used with default settings. The single-point calculations (MP2/6-31G(2d,p) level) in GAMESS [64] at the geometry taken from M05/6$31 \mathrm{G}(2 \mathrm{~d}, \mathrm{p})$ optimizations provided the orbital contours that were drawn with the use of QMView [65].

Acknowledgements Financial support from the Polish Ministry of Science and Higher Education (Grant no. NN204 174138) is
Table 2 Selected crystallographic parameters of 2 and 4

\begin{tabular}{|c|c|c|}
\hline & 2 & 4 \\
\hline Empirical formula & $\mathrm{C}_{9} \mathrm{H}_{5} \mathrm{~F}_{6} \mathrm{~N}_{3} \mathrm{O}_{2}$ & $\mathrm{C}_{11} \mathrm{H}_{5} \mathrm{~F}_{10} \mathrm{~N}_{3} \mathrm{O}_{2}$ \\
\hline Formula weight & 301.16 & 401.18 \\
\hline Crystal system & Monoclinic & Monoclinic \\
\hline Space group & $P 2_{1} / c$ & $P 2{ }_{1} / c$ \\
\hline \multicolumn{3}{|l|}{ Unit cell dimensions } \\
\hline$a(\AA)$ & $4.9550(3)$ & $4.98060(10)$ \\
\hline$b(\AA)$ & $23.3587(12)$ & $27.9899(9)$ \\
\hline$c(\AA)$ & $9.6277(4)$ & $10.0263(3)$ \\
\hline$\beta\left({ }^{\circ}\right)$ & $98.809(3)$ & $92.0470(10)$ \\
\hline Volume $\left(\AA^{3}\right)$ & 1101.19(10) & $1396.84(7)$ \\
\hline$Z$ & 4 & 4 \\
\hline $\begin{array}{l}\text { Density (calculated) } \\
\left(\mathrm{Mg} / \mathrm{m}^{3}\right)\end{array}$ & 1.817 & 1.908 \\
\hline $\begin{array}{l}\text { Absorption coefficient } \\
\left(\mathrm{mm}^{-1}\right)\end{array}$ & 0.196 & 0.220 \\
\hline$F(000)$ & 600 & 792 \\
\hline Crystal size $\left(\mathrm{mm}^{3}\right)$ & $0.35 \times 0.13 \times 0.08$ & $0.35 \times 0.17 \times 0.15$ \\
\hline $\begin{array}{l}\text { Theta range for data } \\
\text { collection }\left({ }^{\circ}\right)\end{array}$ & $2.76-25.00$ & $1.46-25.01$ \\
\hline Index ranges & $\begin{array}{l}-5 \leq h \leq 5 \\
-27 \leq k \leq 27 \\
-11 \leq l \leq 11\end{array}$ & $\begin{array}{l}-5 \leq h \leq 5 \\
-33 \leq k \leq 33 \\
-11 \leq l \leq 11\end{array}$ \\
\hline Reflections collected & 3543 & 4840 \\
\hline Independent reflections & $\begin{array}{l}1908 \\
{\left[R_{\mathrm{int}}=0.0352\right]}\end{array}$ & $\left.\begin{array}{l}2448 \\
{\left[R_{\mathrm{int}}\right.}\end{array}=0.0191\right]$ \\
\hline $\begin{array}{l}\text { Completeness to theta } \\
(\%)\end{array}$ & 98.9 & $100.0 \%$ \\
\hline $\begin{array}{l}\text { Data/restraints/ } \\
\text { parameters }\end{array}$ & $1908 / 2 / 187$ & $2448 / 8 / 241$ \\
\hline Goodness-of-fit on $F^{2}$ & 1.047 & 1.030 \\
\hline $\begin{array}{l}\text { Final } R \text { indices } \\
\quad[\mathrm{I}>2 \sigma(\mathrm{I})]\end{array}$ & $\begin{array}{l}0.0405 / 0.0770 \\
\quad\left(\mathrm{w} R_{2}\right)\end{array}$ & $\begin{array}{l}0.0354 / 0.0826 \\
\quad\left(\mathrm{w} R_{2}\right)\end{array}$ \\
\hline$R$ indices (all data) & $\begin{array}{l}0.0564 / 0.0837 \\
\quad\left(\mathrm{w} R_{2}\right)\end{array}$ & $\begin{array}{l}0.0421 / 0.0868 \\
\quad\left(\mathrm{w} R_{2}\right)\end{array}$ \\
\hline $\begin{array}{l}\text { Largest diff. peak and } \\
\text { hole }\left(\mathrm{e} \AA^{-3}\right)\end{array}$ & 0.229 and -0.239 & 0.335 and -0.357 \\
\hline
\end{tabular}

gratefully acknowledged. The authors are very much indebted to the Academic Computer Centre in Gdansk-TASK and CYFRONET in Cracow for providing computer time and programs.

Open Access This article is distributed under the terms of the Creative Commons Attribution Noncommercial License which permits any noncommercial use, distribution, and reproduction in any medium, provided the original author(s) and source are credited.

\section{References}

1. Watson JD, Crick FHC (1953) Nature 171:737

2. Jeffrey GA, Saenger W (1994) Hydrogen bonding in biological structures, study edition. Springer, Berlin

3. Eldrup AB, Christensen C, Haaima G, Nielsen PE (2002) J Am Chem Soc 124:3254 
4. Prins LJ, Reinhoudt DN, Timmerman P (2001) Angew Chem Int Ed 40:2382

5. Lehn J-M (2000) In: Ciferri A (ed) Supramolecular polymer chemistry-scope and perspectives. Marcel Dekker, New York

6. Brunsveld L, Folmer BJB, Meijer EW, Sijbesma RP (2001) Chem Rev 101:4071

7. De Greef TFA, Smulders MMJ, Wolffs M, Schenning APHJ, Sijbesma RP, Meijer EW (2009) Chem Rev 109:5687

8. Alvares-Rua C, Garcia-Granda S, Goswami S, Mukherjee R, Dey S, Claramunt RM, Santa Maria MD, Rozas I, Jagerovic N, Alkorta I, Elguero J (2004) New J Chem 28:700

9. Newman SG, Taylor A, Boyd RJ (2008) Chem Phys Lett 450:210

10. Pranata J, Wierschke SG, Jorgensen WL (1991) J Am Chem Soc $113: 2810$

11. Jorgensen WL, Pranata J (1990) J Am Chem Soc 112:2008

12. Taubitz J, Lüning U (2009) Aust J Chem 62:1550

13. Sijbesma RP and Meijer EW (2003) Chem. Commun. 5

14. Blight BA, Camara-Campos A, Djurdjevic S, Kaller M, Leigh DA, McMillan FM, McNab H, Slawin AMZ (2009) J Am Chem Soc 131:14116

15. Murray TJ, Zimmerman SC, Kolotuchin SV (1995) Tetrahedron 51:635

16. Bell DA, Anslyn EV (1995) Tetrahedron 51:7161

17. Djurdjevic S, Leigh DA, McNab H, Parsons S, Teobaldi G, Zerbetto F (2007) J Am Chem Soc 129:476

18. Hisamatsu Y, Fukumi Y, Shirai N, Ikeda S-i, Odashima K (2008) Tetrahedron Lett 49:2005

19. McGhee AM, Kilner C, Wilson AJ (2008) Chem Commun 344

20. Xu W, Li X-C, Tan H, Chen G-J (2006) Phys Chem Chem Phys $8: 4427$

21. Park TK, Schroeder J, Rebek J (1991) J Am Chem Soc 113:5125

22. Gooch A, McGhee AM, Renton LC, Plante JP, Lindsay CI, Wilson AJ (2009) Supramol Chem 21:12

23. Sontjens SHM, Sijbesma RP, van Genderen MHP, Meijer EW (2000) J Am Chem Soc 122:7487

24. Schneider H-J (2009) Angew Chem Int Ed 48:3924

25. Scherman OA, Ligthart GBWL, Sijbesma RP, Meijer EW (2006) Angew Chem Int Ed 45:2072

26. Brammer S, Lüning U, Kühl C (2002) Eur J Org Chem 2002: 4054

27. Manesiotis P, Hall AJ, Sellergren B (2005) J Org Chem 70:2729

28. Brown HC (1945) J Am Chem Soc 67:378

29. Brown HC (1945) J Am Chem Soc 67:1452

30. Lüning U, Kühl C (1998) Tetrahedron Lett 39:5735

31. Luening U, Kuhl C, Uphoff A (2002) Eur J Org Chem 2002:4063

32. Benoit RL, Fréchette M, Lefebvre D (1988) Can J Chem 66:1159

33. Beijer FH, Sijbesma RP, Vekemans JAJM, Meijer EW, Kooijman H, Spek AL (1996) J Org Chem 61:6371

34. Llanes-Pallas A, Matena M, Jung T, Prato M, Stohr M, Bonifazi D (2008) Angew Chem Int Ed 47:7726

35. Li Z, Ding J, Robertson G, Day M, Tao Y (2005) Tetrahedron Lett 46:6499

36. Katsuhiro I (2010) Chem Commun 2947

37. Ikeda C, Nagahara N, Motegi E, Yoshioka N, Inoue H (1999) Chem Commun 1759

38. Liu Y, Li Y, Jiang L, Gan H, Liu H, Li Y, Zhuang J, Lu F, Zhu D (2004) J Org Chem 69:9049

39. Liu Y, Zhuang J, Liu H, Li Y, Lu F, Gan H, Jiu T, Wang N, He X, Zhu D (2004) Chem Phys Chem 5:1210

40. Schmidt J, Schmidt R, Wurthner F (2008) J Org Chem 73:6355
41. Kang SO, Day VW, Bowman-James K (2009) J Org Chem $75: 277$

42. Lo PK, Sleiman HF (2008) Macromolecules 41:5590

43. Xu Z, Daka P, Wang H (2009) Chem Commun 6825

44. Chattopadhyay P, Pandey PS (2007) Bioorg Med Chem Lett 17:1553

45. Bolz I, Moon C, Enkelmann V, Brunklaus G, Spange S (2008) J Org Chem 73:4783

46. Forbes CC, Beatty AM, Smith BD (2001) Org Lett 3:3595

47. Feibush B, Figueroa A, Charles R, Onan KD, Feibush P, Karger BL (1986) J Am Chem Soc 108:3310

48. Breinlinger E, Niemz A, Rotello VM (1995) J Am Chem Soc 117:5379

49. Bolz I, Spange S (2008) Chem Eur J 14:9338

50. Chattopadhyay P, Pandey PS (2006) Tetrahedron 62:8620

51. Murray TJ, Zimmerman SC (1992) J Am Chem Soc 114:4010

52. Fenlon EE, Murray TJ, Baloga MH, Zimmerman SC (1993) J Org Chem 58:6625

53. Leung M-K, Mandal AB, Wang C-C, Lee G-H, Peng S-M, Cheng H-L, Her G-R, Chao I, Lu H-F, Sun Y-C, Shiao M-Y, Chou P-T (2002) J Am Chem Soc 124:4287

54. Farrugia LJ (1997) J Appl Crystallogr 30:565

55. Osmialowski B (2009) J Mol Struct THEOCHEM 908:92

56. Bernstein J, Stearns B, Shaw E, Lott WA (1947) J Am Chem Soc 69:1151

57. Kurita K, Williams RL (1975) J Heterocycl Chem 12:789

58. Kolehmainen E, Ośmiałowski B, Krygowski TM, Kauppinen R, Nissinen M, Gawinecki R (2000) J Chem Soc Perkin Trans 2:1259

59. Benesi H, Hildebrand J (1949) J Am Chem Soc 71:2703

60. Otwinowski Z, Minor W (1997) Methods in enzymology. In: Carter CW, Sweet RM (eds) Macromolecular crystallography, vol 276. Academic Press, New York

61. Burla MC, Camalli M, Carrozzini B, Cascarano GL, Giacovazzo C, Polidori G, Spagna R (2005) J Appl Crystallogr 38:381

62. Macrae CF, Bruno IJ, Chisholm JA, Edgington PR, Pidcock E, McCabe P, Rodriguez-Monge L, Taylor R, van de Streek J, Wood PA (2008) J Appl Crystallogr 41:466

63. Frisch MJ, Trucks GW, Schlegel HB, Scuseria GE, Robb MA, Cheeseman JR, Montgomery J, J. A., Vreven T, Kudin KN, Burant JC, Millam JM, Iyengar SS, Tomasi J, Barone V, Mennucci B, Cossi M, Scalmani G, Rega N, Petersson GA, Nakatsuji H, Hada M, Ehara M, Toyota K, Fukuda R, Hasegawa J, Ishida M, Nakajima T, Honda Y, Kitao O, Nakai H, Klene M, Li X, Knox JE, Hratchian HP, Cross JB, Adamo C, Jaramillo J, Gomperts R, Stratmann RE, Yazyev O, Austin AJ, Cammi R, Pomelli C, Ochterski JW, Ayala PY, Morokuma K, Voth GA, Salvador P, Dannenberg JJ, Zakrzewski VG, Dapprich S, Daniels AD, Strain MC, Farkas O, Malick DK, Rabuck AD, Raghavachari K, Foresman JB, Ortiz JV, Cui Q, Baboul AG, Clifford S, Cioslowski J, Stefanov BB, Liu G, Liashenko A, Piskorz P, Komaromi I, Martin RL, Fox DJ, Keith T, Al-Laham MA, Peng CY, Nanayakkara A, Challacombe M, Gill PMW, Johnson B, Chen W, Wong MW, Gonzalez C, Pople JA (2004) Gaussian 03, Revision E.01. Gaussian Inc., Pittsburgh

64. Schmidt MW, Baldridge KK, Boatz JA, Elbert ST, Gordon MS, Jensen JH, Koseki S, Matsunaga N, Nguyen KA, Su SJ, Windus TL, Dupuis M, Montgomery JA (1993) J Comput Chem 14:1347 65. Baldridge KK, Greenberg JP (1995) J Mol Graph 13:63 